\title{
Faktor-Faktor yang Menentukan Keterlibatan Pemuda Pedesaan pada Kegiatan Pertanian Berkelanjutan
}

\section{Determine Factors of Rural Youth Involvement on Sustainable Agriculture Activities}

\author{
Fitri Ningsih ${ }^{1}$, Sofyan Sjaf ${ }^{1}$ \\ ${ }^{1}$ Departemen Sains Komunikasi dan Pengembangan Masyarakat, \\ Fakultas Ekologi Manusia, Institut Pertanian Bogor, Bogor
}

\begin{abstract}
Sustainable agriculture is one of national goal development in the realization of food self-suffiency in Indonesia. Sustainable agriculture will not be realized without the involvement of youth in agricultural activities, which include the activities of land and seed preparation, maintenance, and harvesting. Agricultural activities must be able to meet the economic needs, maintaining land fertility, and recognized by society as decent job. The purpose of this research was to analyze the factors that determine the involvement of rural youth in sustainable agricultural activities. In order to achieve that, the research methodology used qualitative and quantitative methods. Methodology used for quantitative is survey approach. Quantitative data were processed using regression test, rank Spearman test, and cross tabulation. Meanwhile, methodology that used for qualitative is in-depth interview approach. Data obtained from this method were reduced, presented, and drawn for conclusion. Result of the research showed the involvement of youth in agricultural activities had became decreased due to parental socialization and low cohesiveness peers. Agricultures was considered as a job that is not economically viable. Therefore, it needs attention of various sides to improve the socialization of agriculture, and coordinate the institution to facilitate youth sharing information about agriculture.
\end{abstract}

Keywords: rural youth, agricultural activities, sustainable agriculture, development

\begin{abstract}
Abstrak
Pertanian berkelanjutan tidak akan terwujud tanpa adanya keterlibatan pemuda pada kegiatan pertanian, yang meliputi: persiapan lahan dan benih, pemeliharaan, dan panen. Kegiatan pertanian harus mampu memenuhi kebutuhan ekonomi, tetap menjaga kesuburan lahan, dan diakui oleh masyarakat sebagai pekerjaan yang layak. Tujuan penelitian ini adalah menganalisis faktorfaktor yang menentukan keterlibatan pemuda pedesaan pada kegiatan pertanian berkelanjutan. Agar tujuan penelitian tercapai, maka metodologi penelitian yang digunakan adalah kuantitatif dan kualitatif. Untuk metodologi kuantitatif digunakan pendekatan survei. Data kuantitatif diolah dengan menggunakan uji regresi, uji rank spearman, dan tabulasi silang. Sementara itu, metode kualitatif menggunakan pendekatan wawancara mendalam. Data yang diperoleh dari metode ini direduksi, disajikan, dan ditarik kesimpulan. Hasil penelitian menunjukkan bahwa keterlibatan pemuda pada kegiatan pertanian semakin menurun. Faktor yang membuat rendahnya keterlibatan pemuda pada kegiatan pertanian berkelanjutan adalah sosialisasi orangtua dan kohesivitas teman sebaya yang rendah. Pertanian dianggap sebagai pekerjaan yang tidak menjanjikan secara ekonomi. Oleh karena itu, perlu perhatian berbagai pihak untuk meningkatkan sosialisasi mengenai pertanian, serta suatu wadah yang mampu menfasilitasi pemuda untuk saling berbagi informasi mengenai pertanian.
\end{abstract}

Kata kunci: pemuda pedesaan, kegiatan pertanian, pertanian berkelanjutan, pembangunan

\section{Pendahuluan}

Dewasa ini, setiap usaha pembangunan yang melibatkan lingkungan dan sumberdaya alam, pasti akan selalu menyinggung konsep berkelanjutan, termasuk pertanian. Ashari dan Saptana (2007) mendefinisikan pertanian berkelanjutan berdasarkan UUD 1945, pasal 33 yang berbunyi "perekonomian nasional diselenggarakan berdasar atas demokrasi ekonomi dengan prinsip kebersamaan, efisiensi, berkeadilan, berkelanjutan, memiliki wawasan lingkungan, kemandirian, dan serta dengan menjaga keseimbangan kemajuan dan kesatuan ekonomi nasional". Senada dengan Ashari dan Saptana (2007), Notohaprawiro (2006) mendefinisikan kegiatan pertanian berkelanjutan sebagai sebuah sistem pengelolaan pertanian terpadu yang secara berangsur-angsur meningkatkan penghasilan tiap satuan lahan dengan tetap mempertahankan keutuhan dan keanekaragaman ekologi dan hayati sumberdaya alam yang ada dalam jangka panjang, memberikan keuntungan ekonomi bagi setiap 
orang, menyumbang terhadap peningkatan mutu kehidupan, dan memperkuat pembangunan ekonomi negara.

Sehubungan dengan pertanian berkelanjutan, White (2011) menyatakan bahwa peran pemuda pada pertanian harus dipertimbangkan. Populasi penduduk dunia semakin bertambah dari tahun ke tahun. Keadaan ini berimbas kepada meningkatnya kebutuhan pangan dunia. Penduduk yang berusia muda semakin meningkat, namun peningkatan ini tidak diikuti dengan peningkatan ketersediaan lapangan pekerjaan sehingga pengangguran semakin meningkat. Lebih dari setengah populasi negara-negara berkembang adalah penduduk yang tergolong pemuda dan $70 \%$ di antaranya hidup dalam kemiskinan ekstrim, tinggal di daerah pedesaan. Keadaan ini semakin buruk karena ketertarikan pemuda terhadap pertanian semakin berkurang. Padahal menurut pengamatan White (2011), pertanian merupakan salah satu pekerjaan yang sangat dibutuhkan karena sektor ini mampu menyerap tenaga kerja dalam jumlah yang cukup besar, sehingga tidak menutup kemungkinan bahwa ketika pertanian bisa dikembangkan dengan baik, maka sektor ini memiliki potensi yang cukup besar untuk menyediakan pekerjaan bagi banyak orang dan ini akan berdampak pada menurunnya pengangguran di pedesaan.

Sejalan dengan White (2011), Vellema (2011) menyatakan telah muncul indikasi terjadinya fenomena lostgenerationpada pertanian di pedesaan. Indikasi ini diperkuat oleh White yang menyatakan bahwa di Ethiopia, pemudanya tidak mau bertani karena mereka telah memiliki pendidikan yang tinggi, sehingga mereka lebih memilih untuk menunggu pekerjaan yang sesuai dengan pendidikan formal yang diperolehnya. Mereka menghabiskan waktunya untuk mengobrol dengan pemuda lainnya atau menghabiskan dengan menonton televisi. Di India juga terjadi hal yang hampir sama, kebanyakan dari generasi mudanya tidak mau bertani dan lebih memilih bekerja di sektor industri dengan harapan jaminan ekonomi karena pendapatannya rutin tiap bulan. Kasus seperti ini, ternyata juga terjadi di Indonesia. Pemudanya beranggapan bahwa mereka belum pantas untuk berwirausaha karena tidak memiliki kemampuan teknis dalam pertanian dan lebih tergiur dengan gaji bulanan pada pekerjaan formal (White, 2011).
Indikasi terjadinya fenomena lost generation, ternyata mulai muncul di beberapa wilayah pedesaan Indonesia. Data BPS (2010) menunjukkan bahwa pertanian bukan lagi menjadi mata pencaharian primadona bagi pemuda. Mata pencaharian yang paling banyak dilaksanakan adalah perdagangan $(16,8 \%)$, disusul dengan industri pengolahan $(15,93 \%)$, sedangkan pertanian padi dan palawija berada di urutan ketiga dengan presentase 15,75\% (BPS, 2010). Data tersebut merupakan data yang pada aras makro, sehingga sangat penting untuk menganalisis pembuktian kasus tersebut pada tahap mikro. Oleh karena itu, penelitian ini dilaksanakan di salah satu desa Kecamatan Pamijahan yaitu Desa Purwabakti.

Menurut White (2011), ketika ingin memahami pemuda sebagai generasi penerus, maka kita juga harus memahami pentingnya pendekatan relasional. Maksudnya, pemuda harus dilihat sebagai bagian dari dinamika hubungan pemuda dengan orang lain (orang dewasa) dalam struktur yang lebih besar dari reproduksi sosial. Konsep ini menunjukkan bahwa orang lain yang ada di sekitar pemuda akan berpengaruh terhadap tindakan dan keputusan pemuda termasuk keputusan untuk terlibat di pertanian atau mencari pekerjaan di sektor lainnya. Pihak-pihak yang berpengaruh tersebut adalah orangtua, teman sebaya, serta masyarakat sebagai lingkungan sosial bagi pemuda. Orangtua merupakan orang yang paling dekat pemuda. Hampir semua tindakan dan perilaku anak biasanya akan sangat di-pengaruhi oleh pengajaran orangtua, termasuk salah satunya pengajaran orangtua terkait bekerja di sektor pertanian. Begitu juga dengan teman sebaya, sebagai pihak yang sering bergaul dan berbagi pikiran dengan pemuda.

Saat ini semakin banyak orangtua yang tidak mengajak anak-anaknya untuk bertani karena berbagai alasan. Bahkan ada orangtua yang secara terang-terangan melarang anak-anaknya untuk bekerja di sektor pertanian. Pertanian dianggap sebagai sektor yang tidak menjanjikan untuk kehidupan yang lebih layak. Pertanian merupakan jenis pekerjaan yang membutuh kerja keras, menguras waktu, dan tenaga, tetapi penghasilan yang diperoleh tidak menentu. Selain pengaruh dari pihak-pihak tersebut, pemuda juga dipengaruhi oleh sistem sosial yang ada di lingkungan tempat tinggalnya, termasuk kearifan lokal yang hanya 
berlaku di wilayah itu saja. Kearifan lokal yang dimaksudkan pada tulisan ini adalah sulitnya proses pelepasan lahan atau usaha keluarga dalam mempertahankan lahan yang dimiliki keluarga. Nugraha (2012), menambahkan bahwa faktor lain yang bisa mempengaruhi keterlibatan pemuda pada kegiatan pertanian adalah tingkat penguasaan lahan keluarga.

Besarnya peran pemuda terhadap pertanian berkelanjutan, membuat bentuk keterlibatannya pada kegiatan pertanian juga harus dipertimbangkan. Kegiatan pertanian padi sawah didefinisikan Hidayat (2010) sebagai semua rangkaian kegiatan pertanian mulai dari mempersiapkan lahan, menanam, memelihara, sampai masa panen. Kegiatan tersebut bisa digolongkan menjadi tiga yaitu kegiatan persiapan lahan dan benih, pemeliharaan, dan panen. Berdasarkan penjelasan tersebut, maka sangat penting untuk menganalisis hubungan bentuk keterlibatan pemuda di sektor pertanian dengan kontribusinya untuk terwujudnya pertanian berkelanjutan di pedesaan.

Berdasarkan latar belakang di atas, maka rumusan masalah yang dikaji dalam penelitian ini sebagai berikut: 1) apa saja bentuk-bentuk keterlibatan pemuda pada kegiatan pertanian di Desa Purwabakti?; 2) apakah faktor-faktor yang paling menentukan keterlibatan pemuda pada kegiatan pertanian?; dan 3) bagaimana korelasi antara bentuk keterlibatan pemuda pada kegiatan pertanian padi sawah dengan pertanian berkelanjutan di pedesaan? Atas rumusan masalah tersebut, maka tujuan umum penelitian ini adalah menganalisis faktor-faktor terkait yang paling menentukan tingkat keterlibatan pemuda pada kegiatan pertanian berkelanjutan. Sementara itu, tujuan khusus penelitian ini adalah: 1) menganalisis bentuk-bentuk keterlibatan pemuda pada kegiatan pertanian di Desa Purwabakti; 2) menganalisis faktor-faktor yang menentukan keterlibatan pemuda pada kegiatan pertanian di Desa Purwabakti; dan 3) menganalisis korelasi keterlibatan pemuda pada kegiatan pertanian dengan pertanian berkelanjutan di Desa Purwabakti.

Pemuda menurut Undang-Undang Nomor 40 Tahun 2009 pasal 1 ayat 1, "pemuda adalah warga negara Indonesia yang memasuki periode penting pertumbuhan dan perkembangan yang berusia 16 sampai 30 tahun". Definisi yang berbeda dinyatakan oleh White (2011), bahwa pemuda adalah penduduk dengan usia mulai dari 18 sampai 40 tahun. Berdasarkan penelitian Untari et al. (2007) karakteristik individu pemuda tidak berpengaruh terhadap keterlibatan pemuda di pertanian karena hal yang paling berpengaruh adalah akses terhadap informasi. Semakin tinggi akses pemuda terhadap informasi pertanian, maka semakin besar pengaruhnya terhadap perilaku yang ditunjukkan pemuda dalam pelaksanaan pertanian di pedesaan. Berdasarkan pendefinisian tersebut, penulis menyatakan bahwa pemuda yang menjadi unit analisis penelitian ini adalah pemuda yang berjenis kelamin laki-laki dengan umur 16 sampai 30 tahun. Pemuda yang termasuk pada kriteria inilah yang dikategorikan sebagai subjek penelitian dan dilakukan identifikasi bentuk kerterlibatannya pada kegiatan pertanian padi sawah.

Hidayat (2010) menjelaskan bahwa kegiatan pertanian mencakup persiapan lahan, penyemaian benih, penanaman, pemupukan, penyiangan gulma, pembasmian hama, pengairan, dan panen. Namun, penelitian yang dilakukan Nugraha (2012), lebih berfokus pada keterlibatan pemuda pada saat panen. Ini disebabkan karena pemuda masih sekolah sehingga orangtua tidak mau membebani anak-anaknya dengan kegiatan-kegiatan pertanian lainnya. Penulis berpandangan bahwa penelitian yang hanya berfokus pada masa panen kurang mampu mereplikakan kenyataan yang sebenarnya. Ketika melihat keterlibatan pemuda di sektor pertanian, maka sebaiknya dilihat bagaimana keterlibatan pemuda pada semua kegiatan pertanian. Oleh karena itu, keterlibatan pemuda pada kegiatan pertanian ditinjau dari semua kegiatan tersebut. Rangkaian kegiatan pertanian yang cukup banyak, akan mempersulit pengukuran keterlibatan pemuda pada setiap tahapan kegiatan pertanian. Oleh karena itu, kegiatan pertanian dikelompokkan menjadi tiga bagian utama, yaitu: pertama persiapan lahan dan penyemaian benih, meliputi: membajak sawah, membenamkan gulma, memilah padi untuk benih, dan meredam benih, kedua pemeliharaan, meliputi: kegiatan penanaman, pemupukan, penyiangan gulma, pembasmian hama, dan pengairan, dan ketiga panen, meliputi: membabat tanaman padi, memisahkan bulir padi dengan batangnya, dan menjemur bulir padi. Pemerintah menyatakan bahwa kegiatan pertanian yang diterapkan oleh petani, dianjurkan mengandung unsur-unsur pertanian 
berkelanjutan, mengingat ketersediaan lahan yang semakin sedikit sedangkan kebutuhan pangan terus meningkat akibat jumlah penduduk yang terus bertambah dari tahun ke tahun.

Pertumbuhan penduduk di dunia juga tergolong tinggi bahkan jumlah penduduk dunia telah melebihi angka 7 miliar jiwa pada tahun 2010 . Peningkatan jumlah penduduk ini tentu saja akan meningkatkan jumlah kebutuhan pangan dunia. Oleh karena itu, semua kegiatan pertanian harus menggunakan konsep pertanian berkelanjutan. FAO mendefinisikan pertanian berkelanjutan sebagai berikut: "the management and conservation of the natural resource base, and the orientation of technological and institutional change in such a manner as to ensure the attainment and continued satisfaction of human needs for present and future generations. Such development such as conserves land, water, plant and animal genetic resources, is environmentally non-degrading, technically appropriate, economically viable and socially acceptable'. Hampir sama dengan pendefinisian FAO, Notohaprawiro (2006) mendefinisikan pertanian berkelanjutan sebagai sistem pengelolaan pertanian terpadu yang secara berangsur-angsur mampu meningkatkan penghasilan setiap satuan lahan dengan mempertahankan keutuhan dan keanekaragaman ekologi dan hayati sumberdaya alam untuk jangka panjang, memberikan keuntungan ekonomi kepada petani, menyumbang kepada mutu kehidupan dan memperkuat pembangunan ekonomi negara.

Ketika proses pemeliharaan, penelitian Ashari dan Saptana (2007) menyatakan bahwa penggunaan pupuk kimia seperti urea, TSP, dan SP36 menimbulkan residu zat kimia di dalam tanah dan air. Begitu pula dengan penggunaan pestisida, jumlah dan kadar pestisida yang berlebihan akan menimbulkan resistensi dan resurjensi berbagai hama dan penyakit. Akibatnya serangan hama dan penyakit semakin banyak dan sulit untuk dikendalikan. Keadaan ini diperparah dengan globalisasi ekonomi yang mengakibatkan terintegrasinya berbagai berbagai aspek perekonomian suatu negara dengan perekonomian dunia, serta meningkatnya persaingan baik antarpelaku agribisnis maupun antarnegara. Oleh karena itu, diperlukan usaha untuk melindungi para petani Indonesia dari persaingan dunia luar, dan usaha untuk meningkatkan hasil pertanian tetapi tidak merusak sumberdaya.

Zamora (1995) dalam penelitian Untari et al. (2007) menjelaskan pertanian berkelanjutan secara lebih mendetail berupa adanya 5 prinsip pertanian berkelanjutan, yaitu adanya kelayakan ekonomi. Kelayakan ekonomi berarti para petani memiliki pendapatan yang positif sebagai upah dari tenaga kerja yang telah dicurahkannya, yang akan dimanfaatkan sebagai biaya untuk menjamin kesejahteraan keluarga petani.

Sistem pertanian paling tidak menyediakan makanan dan kebutuhan dasar lain bagi keluarga petani; pertanian ekologis dan ramah lingkungan. Sistem pertanian yang ramah lingkungan diintegrasikan untuk sistem ekologi yang lebih luas dan terfokus pada pemeliharaan sumberdaya alam dan juga keanekaragaman hayati serta menghindari kegiatan yang dapat menyebabkan dampak lingkungan negatif. Salah satu jenis upaya pengelolaan lingkungan hidup khususnya bagi masyarakat petani adalah melalui penerapan kembali sistem kegiatan pertanian ekologis. Ketergantungan petani akan keberadaan benih, pupuk kimia serta pestisida kimia menyebabkan kehidupan petani sebagai produsen utama bahan makanan pokok tidak pernah bertambah baik.

Sistem pertanian yang diterima secara sosial bisa ditinjau dari sikap menghormati harga diri dan hak individu dan hak kelompok serta memperlakukan mereka secara baik dan adil, membuka akses informasi, pasar dan sumberdaya pertanian terkait lainnya terutama lahan. Akses yang sama juga disediakan untuk semua jenis kelamin, lembaga sosial, agama, suku serta keadilan bagi generasi saat ini dan generasi mendatang. Distribusi tenaga kerja pada lahan pertanian berkelanjutan, bisa terdistribusi dari tahun ke tahun. Keadilan distribusi tenaga kerja di antara anggota keluarga adalah indikator produktivitas manusia dalam lahan pertanian. Sangat baik jika seluruh anggota keluarga produktif.

Sistem pertanian yang menganut kesesuaian budaya mempertimbangkan nilai budaya termasuk kepercayaan agama dan tradisi dalam pembangunan sistem, rencana, dan program pertanian. Kearifan lokal merupakan unsur kebudayaan tidak dapat dikatakan mendukung pertanian berkelanjutan jika tidak mengakar dan dipraktekan dalam kehidupan masyarakat. 
Sistem pertanian dengan pandangan holistik melihat pertanian sebagai sistem pertanian dan pendekatan sistem serta hubungannya dalam hal biofisik, sosial ekonomi, kebudayaan dan faktor politik. Sistem ini juga mempertimbangkan interaksi dinamis antara kegiatan on-farm, off-farm dan non-farm serta mengakui kegiatan-kegiatan ini merupakan komplemen satu sama lain.

Berbeda dengan pendefinisian sebelumnya, Vellema (2011) menjelaskan bahwa sistem pertanian berkelanjutan membutuhkan perubahan terutama pada aspek manajemen kelembagaan. Perubahan manajemen yang dikupas mencakup perubahan pada sistem manajemen keuangan, manajemen politik pemerintahan, perubahan sistem sosial, perubahan teknologi pertanian. Semua perubahan tersebut harus mengintegrasikan antara tiga stakeholders yaitu masyarakat (petani), pemerintah, dan swasta. Semua peraturan yang akan menghambat kemajuan pertanian harus segera dirubah. Proses peminjaman modal bagi petani harus dipermudah dengan bunga yang tidak memberatkan petani.

Berdasarkan beberapa konsep mengenai pertanian berkelanjutan tersebut, penulis menyimpulkan bahwa pertanian berkelanjutan memiliki indikator utama yang harus dipenuhi yaitu kelayakan ekonomi, ekologi, dan sosial. Kelayakan ekonomi menunjukkan bahwa pertanian berkelanjutan bisa memberikan penghidupan yang layak bagi para pekerja di sektor pertanian terutama bagi petaninya. Mereka mampu memenuhi kebutuhan sehari-hari, mampu membayar pendidikan anak-anaknya dan memiliki akses terhadap fasilitas kesehatan. Kelayakan ekologi menunjukkan bahwa sistem pertanian berkelanjutan bisa memelihara kesuburan lahan sehingga lahan pertanian bisa dimanfaatkan dalam jangka waktu panjang untuk generasi yang akan datang. Hasil pertanian yang diperoleh dari waktu ke waktu tidak berkurang karena keseimbangan kesuburan lahan serta berbagai macam tanaman bisa ditanam pada lahan tersebut, tidak satu jenis tanaman tertentu saja. Lain halnya dengan kelayakan ekonomi dan ekologi, kelayakan sosial menunjukkan bahwa pertanian berkelanjutan diterima secara sosial oleh masyarakat sebagai pekerjaan yang layak dan menjanjikan sehingga fenomena "waithood" yaitu kecemasan menunggu pekerjaan, perumahan, dan pernikahan yang biasanya tergantung pekerjaan, bisa diatasi.

Pranadji (1999) dalam Herlina (2002), menjelaskan bahwa pertanian di Yogyakarta dikelola generasi tua yang memang dari semula sudah berprofesi sebagai petani atau yang harus bertani karena tidak memiliki peluang kerja pada sektor lain. Dia menjelaskan bahwa terdapat tendensi bahwa pemuda pedesaan mulai menghindari bekerja atau berusaha pada sektor pertanian karena memandangnya sebagai pekerjaan yang kotor, kolot, dan melelahkan. Ketidaktertarikan itu juga disebabkan hasil produksi pertanian yang diperoleh sangat lama dan sering kali tidak memuaskan. Akibat dari persepsi ini, tingkat pengangguran yang ada di pedesaan semakin membesar. Ben White menjelaskan jumlah petani di negara berkembang semakin berkurang karena pemuda pedesaan yang tumbuh disekitar pertanian dan melihat kotornya proses pertanian, tenaga dan waktu yang harus dikeluarkan sangat besar, tetapi hasil yang tidak menentu, membuat pertanian menjadi profesi yang tidak menarik lagi bagi mereka (White, 2011).

\section{Metode Penelitian}

Penelitian ini merupakan penelitian survai. Teknik survai adalah penelitian yang mengambil sampel dari suatu populasi dengan menggunakan kuesioner penelitian sebagai alat pengumpul data. Tipe penelitian yang digunakan adalah explanatory research yaitu penelitian yang sifat analisisnya menghubungkan antara variabel melalui uji hipotesis (Singarimbun dan Effendi, 2008).

Penelitian ini menggunakan paduan metode kuantitatif dan juga kualitatif. Metode kuantitatif dilakukan dengan menggunakan teknik survei dengan menggunakan instumen kuesioner terstruktur, yang memuat sejumlah pertanyaan terkait dengan variabel penelitian yang akan dilakukan. Sementara itu, metode kualitatif dilakukan dengan observasi lapang dengan menggunakan panduan pertanyaan wawancara mendalam. Tujuan dari menggunakan metode kualitatif adalah untuk dapat lebih memahami permasalahan di lokasi penelitian secara lebih mendalam dan menyeluruh.

Penelitian ini menggunakan data primer dan data sekunder. Data primer diperoleh dari hasil penelitian di lapangan, sedangkan data sekunder merupakan data yang diperoleh dari studi 
literatur penelitian-penelitian yang telah dilakukan sebelumnya. Data-data sekunder didukung dengan adanya dokumen-dokumen mengenai monografi lokasi penelitian dan data pemuda dari lembaga pemerintahan setempat.

Lokasi penelitian dilakukan di Desa Purwabakti, Kecamatan Pamijahan, Kabupaten Bogor. Penelitian ini diharapkan relevan dengan tujuan penelitian sehingga data yang diperoleh bisa menjawab rumusan masalah penelitian. Adapun pertimbangan penentuan desa lokasi penelitian adalah sebagai berikut: 1) terdapat beberapa orang pemuda di desa ini telah berinisiatif untuk membentuk kelompok tani pemuda, 2) kelompok tani pemuda tersebut mempengaruhi pemuda lainnya yang tidak bertani untuk ikut terlibat dalam kegiatan pertanian di desa tersebut.

Populasi penelitian adalah semua warga yang berjenis kelamin laki-laki dengan kriteria umur 16 sampai 30 tahun yang ada di Desa Purwabakti, Kecamatan Pamijahan, Kabupaten Bogor. Penelitian memfokuskan pada pemuda lakilaki karena kegiatan pertanian yang diteliti adalah padi sawah, memiliki tahapan-tahapan yang banyak dan perempuan biasanya hanya dapat mengikuti beberapa kegiatan tersebut. Ada budaya di beberapa daerah yang menilai bahwa perempuan tidak layak mencangkul karena merupakan pekerjaan yang berat dan biasanya dikerjakan laki-laki. Laki-laki memiliki peluang yang besar untuk melaksanakan semua tahapan pertanian yang akan diteliti. Teknik pengambilan sampel menggunakan teknik simple random sampling dengan jumlah responden yang diambil sebanyak 60 orang pemuda, dengan unit analisis individu pemuda.

Penentuan 60 orang responden dilakukan dengan beberapa tahapan sebagai berikut: 1) data masyarakat yang sesuai dengan kriteria yang ditentukan, yaitu pemuda yang berjenis kelamin laki-laki dan berumur 16-30 tahun, 2) pengacakan responden yang terpilih dengan mengunakan microsoft excel, 3) pemuda yang terpilih, namun tidak dapat ditemui pada saat penelitian, akan ditentukan nama lain sebagai pengganti yang diambil berdasarkan angka acak selanjutnya. Berdasarkan langkah-langkah tersebut, maka diperoleh 60 orang pemuda dari 685 pemuda yang ada di Desa Purwabakti. Informan kunci berasal dari tokoh desa, lembaga pemerintahan setempat, ketua lembaga kepemudaan, dan tokoh-tokoh lainnya yang berkaitan dengan penelitian. Nama informan dan responden disamarkan untuk menjaga kerahasiaan identitas

Data primer yang diperoleh, diberikan pengkodean, kemudian dimasukkan (entry) ke dalam sistem data microsoft exce/2010 dan aplikasi spss 16 for windows untuk menguji kecenderungan diterima atau ditolaknya sejumlah hipotesis penelitian (Priyatno, 2013). Pengujian hipotesis penelitian dilaku-kan dengan menggunakan uji regresi dan uji korelasi rank Spearman, dan tabulasi silang. Uji regresi digunakan untuk melihat faktorfaktor yang menentukan keterlibatan pemuda pada kegiatan pertanian, sedangkan uji korelasi rank Spearman digunakan untuk melihat hubungan antara keterlibatan pemuda pada kegiatan pertanian dengan pertanian berkelanjutan. Proses pengaruh dan hubungan antar variabel akan dijelaskan oleh hasil tabulasi silang. Selanjutnya, penelitian didukung dengan data kualitatif yang diperoleh melalui wawancara mendalam dan observasi lapang. Tahapan pengolahan data kualitatif adalah: 1) reduksi data, 2) penyajian, 3) penarikan kesimpulan.

\section{Hasil dan Pembahasan}

\section{Letak Geografis dan Keadaan Lingkungan}

Desa Purwabakti merupakan satu dari sekian desa di Kecamatan Pamijahan, Kabupaten Bogor. Namun, secara geografis, jarak Purwabakti cukup jauh dari pusat Kabupaten Bogor dan justru lebih dekat dengan Kabupaten Sukabumi. Desa Purwabakti terdiri dari 5 Dusun, 12 Rukun Warga (RW), 18 kampung, serta 39 Rukun Tangga (RT). Jumlah penduduk Desa Purwabakti mencapai 7.731 jiwa, yang terdiri dari 3.882 jiwa penduduk laki-laki dan 3.849 jiwa penduduk perempuan.

Adapun luas wilayah Purwabakti mencapai 877,36 hektar. Sebanyak 91,87\% lahan yang ada di Purwabakti dimanfaatkan sebagai lahan pertanian, yaitu ladang dan sawah. Hal ini menunjukkan bahwa Purwabakti memiliki potensi pertanian yang besar dari aspek ketersediaan lahan. Walaupun luas lahan kering lebih besar, penelitian ini berfokus pada pertanian padi sawah karena lahan kering yang ada di Purwabakti merupakan lahan yang tidak dimanfaatkan masyarakat untuk menanam 
Tabel 1 Jumlah dan Persentase Tingkat Keterlibatan 60 Orang Pemuda pada Kegiatan Pertanian di Desa Purwabakti Tahun 2013

\begin{tabular}{llcc}
\hline \multicolumn{1}{c}{$\begin{array}{c}\text { Tingkat Keterlibatan Pemuda pada } \\
\text { Kegiatan Pertanian }\end{array}$} & Kategori & (\%) Persen & (\%) Total \\
\hline Keterlibatan pemuda pada persiapan lahan & Tinggi & 18,33 & \\
dan benih & Sedang & 43,33 & 100,00 \\
& Rendah & 38,34 & \\
Keterlibatan pemuda pada kegiatan & Tinggi & 21,67 & \\
pemeliharaan & Sedang & 25,00 & 100,00 \\
& Rendah & 53,33 & \\
Keterlibatan pemuda pada kegiatan panen & Tinggi & 80,00 & \\
& Sedang & 6,67 & 100,00 \\
& Rendah & 13,33 & \\
\hline
\end{tabular}

tanaman yang bernilai ekonomi tinggi. Lahan kering yang luas tersebut hanya dibiarkan saja ditanami oleh tanaman liar dan beberapa orang masyarakat mengambil kayu bakar yang ada di hutan.

\section{Potensi Sumberdaya Alam dan Hubungan Sosial Masyarakat}

Sejak dulu Purwabakti dikenal sebagai lumbung padi Kecamatan Pamijahan. Mata pencaharian utama masyarakat dari jaman dahulu adalah pertanian. Hal ini didukung kondisi lahan yang subur. Jenis tanaman yang tumbuh di desa ini pun beragam, mulai dari padi, sayuran, sampai kelapa sawit dan teh bisa tumbuh subur di wilayah ini. Berbagai buah-buahan, seperti: nangka, rambutan, dan pisang juga merupakan salah satu potensi sumber daya alam di Purwabakti. Desa Purwabakti dialiri oleh sebuah sungai panjang dari kaki gunung salak. Hal ini menjadi rezeki lainnya bagi masyarakat. jumlah air yang berlimpah tersebut dapat dimanfaatkan untuk mengairi kolam budidaya ikan. Budidaya ikan yang dulunya hanya sebagai mata pencaharian sampingan untuk dapat memenuhi kebutuhan protein keluarga, akhirnya menjadi lahan mata pencaharian baru bagi masyarakat. Banyak warga yang kemudian akhirnya menekuni pekerjaan ini. pekerjaan yang tidak terlalu berat namun keuntngan yang diperoleh cukup besar.

Mata pencaharian utama sebagai petani mulai bergeser ketika ada masyarakat yang merantau ke kota. Ketika di kota, mereka belajar menjadi pengrajin kayu. Setelah bisa membuka usaha sendiri, mereka pulang ke Purwabakti dan mengembangkan usaha kerajinan kayu atau meubel. Mereka menjadi pengrajin kayu dan membuat peralatan, seperti lemari, pintu, dan peralatan lainnya dari kayu. Pekerjaan yang bisa dilakukan di rumah, tidak menyita banyak waktu, serta dengan penghasilan yang lebih besar. Disini mulai beralihnya ketertarikan masyarakat dari pertanian menjadi pengrajin kayu. Pihak yang paling tertarik adalah pemuda dan masyarakat yang tidak memiliki lahan. Harga sewa lahan semakin mahal, harga pupuk dan pestisida melambung, serta hama yang sulit dikendalikan membuat mereka menyerah bertani dan beralih pada jenis pekerjaan ini. Walaupun keadaannya telah berubah, hubungan sosial masyarakat masih tetap terjaga. Rasa kekeluargaan masih ada dan mata pencaharian sebagai petani pun tidak dianggap sebagai pekerjaan yang lebih rendah dibandingkan sebagai pengrajin kayu.

\section{Proses Kegiatan Pertanian}

Pertanian merupakan mata pencaharian turun temurun dari nenek moyang masyarakat Purwabakti. Sebagai desa yang berfokus pada kegiatan pertanian, maka efek revolusi hijau yang digalakkan pemerintah pada masa Orde Baru juga telah diterapkan di wilayah ini. Penggunaan pupuk dan pestisida kimia sudah menjadi hal yang biasa atau bahkan suatu keharusan untuk digunakan pada kegiatan pertanian. Hasil pertanian dianggap akan berkurang ketika penggunaan bahan-bahan kimia tersebut dihentikan. Namun, seiring dengan 
Tabel 2 Hasil Uji Regresi Faktor yang Menentukan Keterlibatan Pemuda pada Kegiatan Pertanian di Desa Purwabakti Tahun 2013

\begin{tabular}{lccc}
\hline \multicolumn{1}{c}{$\begin{array}{c}\text { Faktor yang Mempengaruhi } \\
\text { Keterlibatan Pemuda }\end{array}$} & \multicolumn{2}{c}{ Bentuk Keterlibatan Pemuda pada Kegiatan Pertanian } \\
& Persiapan lahan & Pemeliharaan & Panen \\
\hline Sosialisasi orangtua & $\mathbf{T}$ & $\mathbf{t}$ & $\mathbf{t}$ \\
Kohesivitas teman sebaya & 2,252 & 3,208 & 0,276 \\
Kesulitan proses pelepasan lahan & 5,172 & 4,268 & 2,747 \\
Luas penguasaan lahan & 2,289 & 0,487 & $-0,496$ \\
keluarga & 1,069 & 2,374 & 1,461 \\
\hline
\end{tabular}

berjalannya waktu, petani sudah mulai sadar akan dampak penggunaan bahan-bahan kimia terhadap kesuburan lahan dan kualitas hasil panen. Oleh karena itu, petani di Desa Purwabakti sekarang sudah mulai berusaha mengurangi penggunaan pupuk dan pestisida kimia.

Salah seorang informan menjelaskan bahwa kegiatan pertanian di Purwabakti masih dilakukan dengan cara yang tradisional. Proses membajak sawah masih menggunakan cara yang sederhana, yaitu dicangkul. Masyarakat tidak bisa menggunakan mesin traktor karena kondisi geografis lahan yang miring dan piringan sawah yang kecil. Hal ini akan menyulitkan ketika akan memindahkan mesin traktor. Ketika proses panen pun mereka masih menggunakan ani ani atau dipukulkan kekayu untuk memisahkan bulir padi dengan jeraminya. Salah satu pengetahuan lokal masyarakat yang menarik adalah mereka tidak membakar jerami sisa panen, tetapi mereka membiarkan di lahan sawah dan setelah beberapa hari dibalikkan dengan cangkul. Secara ilmiah ini sangat bagus karena jerami akan membusuk dan akan menjadi pupuk organik bagi lahan. Ketika jerami dibolak-balikan, akan memunculkan mikroba yang akan membantu proses pembusukan sehingga waktu yang dibutuhkan lebih sedikit.

\section{Karakteristik Responden}

Responden dari penelitian ini adalah 60 orang pemuda asli Purwabakti yang berjenis kelamin laki-laki dengan kisaran umur 16 sampai 30 tahun. Responden lebih banyak berasal dari RW 1 sampai RW 7 dengan pertimbangan bahwa RW 8 sampai RW 12 merupakan RW yang berdekatan dengan wilayah perkebunan dan taman nasional, sehingga masyarakatnya cenderung meninggalkan pertanian dan menjadi buruh perkebunan. Tingkat kesuburan lahan pada wilayah ini pun lebih banyak lahan kering dan tidak cocok untuk pertanian padi sawah, berbeda dengan RW 1 sampai RW 7 yang memiliki lahan yang subur dan sangat cocok untuk kegiatan pertanian.

Tingkat pendidikan responden tergolong sedang dan rendah, $40 \%$ dari responden berpendidikan SD, 40\% berpendidikan SMP, dan $20 \%$ berpendidikan SMA dan Perguruan Tinggi. Hal ini tidak mengherankan terjadi karena fasilitas pendidikan yang ada di Purwabakti hanyalah satu yaitu sekolah dasar. Sementara itu, pada aspek pekerjaan, terdapat 35\% (21 orang) dari 60 orang pemuda yang bekerja sebagai petani. Pemuda yang bekerja sebagai petani terdiri dari 15 orang petani yang menggarap lahannya sendiri dan 6 orang buruh tani. Pemuda yang menjadi buruh tani biasanya disebabkan tidak adanya lahan. Biasanya mereka hanya menjadi buruh tani pada saat menggarap lahan dan panen.

Sementara itu, responden yang bekerja sebagai pegawai sebanyak 5\% (3 orang). Pekerjaan yang digolongkan sebagai pegawai adalah guru dan pegawai koperasi. Pemuda yang bekerja sebagai pedagang sebanyak 8,33\% (5 orang). Biasanya mereka ke luar desa bahkan ke luar kota untuk menjual hasil kerajinan kayu. Responden yang masih menjadi pelajar ada sebanyak 11,67\% (7 orang). Pemuda yang tidak bekerja di desa, biasanya akan menjadi buruh bangunan di kota. Ada sebanyak 3,33\% atau sebanyak 2 orang responden yang bekerja sebagai buruh bangunan. Pemuda yang berwiraswasta ada sebanyak 31,67\% (19 orang). 
Tabel 3 Persentase Pendapat Pemuda Mengenai Pertanian Berkelanjutan di Desa Purwabakti Tahun 2013

\begin{tabular}{lccc}
\hline \multicolumn{1}{c}{ Pertanian Berkelanjutan } & Kategori & (\%) Persentasi & (\%) Total \\
\hline Tingkat kelayakan ekonomi & Tinggi & 13,34 & \\
& Sedang & 43,33 & 100,00 \\
& Rendah & 43,33 & \\
Tingkat kelayakan ekologi & Tinggi & 78,33 & \\
& Sedang & 15,00 & 100,00 \\
\multirow{2}{*}{ Tingkat kelayakan sosial } & Rendah & 6,7 & \\
& Tinggi & 70,00 & \multirow{2}{*}{100,00} \\
& Sedang & 21,67 & \\
\hline
\end{tabular}

Pekerjaan yang digolongkan sebagai wiraswasta adalah usaha pengrajin kayu, bengkel kendaraan, dan usaha budidaya ikan emas. Sisanya pemuda yang bekerja sebagai supir yaitu sebanyak 5\% (3 orang). Hasil paling menonjol dari gambar tersebut adalah presentase pemuda yang bekerja pada sektor pertanian dan wiraswasta hanya terpaut 3,33\% atau 2 orang saja. Hal ini mengindikasikan bahwa pemuda yang bertani sudah mulai sedikit dan beralih pada pekerjaan lain di luar pertanian. Pemuda yang berwiraswasta semakin banyak jumlahnya karena pekerjaannya cenderung lebih mudah dibandingkan dengan kegiatan pertanian dengan hasil yang lebih besar. Penghasilan rutin dan hasil yang lebih cepat diperoleh dibandingkan pertanian padi sawah, membuat pemuda semakin enggan untuk bertani.

\section{Bentuk Keterlibatan Pemuda Pada Kegiatan Pertanian}

Kegiatan pertanian merupakan serangkaian kegiatan yang dilakukan mulai dari proses mempersiapkan lahan, benih, pemupukan, pestisida, penyiangan gulma, sampai kegiatan panen. Oleh karena itu, kegiatan pertanian bisa dikelompokkan menjadi tiga kegiatan yaitu: 1) persiapan lahan dan benih, 2) pemeliharaan, 3) panen (Tabel 1).

Keterlibatan pemuda pada kegiatan pertanian semakin menurun terutama pada tahapan persiapan lahan, benih, dan pemeliharaan tanaman. Rendahnya keterlibatan pemuda pada kegiatan persiapan lahan dan benih disebabkan kegiatan pada tahap ini membutuhkan waktu dan tenaga yang besar. Pandangan pemuda bahwa kegiatan pada tahapan ini merupakan pekerjaan yang kuno dan kotor, membuat semakin besar pemuda yang mau terlibat pada tahapan ini. Berbeda dengan keterlibatan pemuda pada kegiatan persiapan lahan dan benih, alasan pemuda yang tidak terlibat pada kegiatan pemeliharaan adalah kegiatan yang dianggap tidak terlalu krusial dalam proses pertanian. Hal ini terbukti dengan pemberian pupuk dan pestisida yang tidak teratur, serta sistem pengairan yang tidak terawat. Alasan lainnya yang membuat pemuda enggan untuk terlibat pada kegiatan pemeliharaan adalah kebiasaan pemuda bermigrasi ke luar desa setelah masa tanam selesai.

Salah satu hal yang menarik adalah keterlibatan pemuda pada kegiatan panen sangat tinggi. Hal ini sangat erat kaitannya dengan tradisi panen raya yang ada di Desa Purwabakti. Semua anggota keluarga akan bersama-sama ke sawah untuk membantu proses pertanian. Tradisi panen raya merupakan bentuk suka cita warga atas hasil panen yang diperoleh. Selain itu, masa panen yang singkat dan harus dilakukan dengan segera. Ketika proses panen dilakukan dalam waktu yang lama, maka padi yang telah siap panen (menguning) banyak yang akan meluruh ke sawah, akibatnya hasil pertanian yang diperoleh oleh petani semakin sedikit. Usaha untuk menghindari munculnya kerugian inilah yang menimbulkan keinginan untuk tetap mendorong agar tradisi yang telah ada secara turun temurun ini bisa bertahan sampai saat ini.

\section{Faktor-Faktor yang Menentukan Keterlibatan Pemuda pada Kegiatan Pertanian}

Faktor yang mempengaruhi keterlibatan pemuda pada kegiatan pertanian, yang mencakup: 
Tabel 4 Hasil Uji Korelasi Rank Spearman antara Keterlibatan Pemuda pada Kegiatan Pertanian dengan Pertanian Berkelanjutan di Desa Purwabakti Tahun 2013

\begin{tabular}{lccc}
\hline $\begin{array}{c}\text { Keterlibatan pemuda pada } \\
\text { kegiatan pertanian }\end{array}$ & $\begin{array}{c}\text { Pertanian berkelanjutan } \\
\text { Koefisien korelasi } \\
\text { kelayakan ekonomi }\end{array}$ & $\begin{array}{c}\text { Koefisien korelasi } \\
\text { kelayakan ekologi }\end{array}$ & $\begin{array}{c}\text { Koefisien korelasi } \\
\text { kelayakan sosial }\end{array}$ \\
\hline Persiapan lahan dan benih & $0,560^{* *}$ & $0,456^{* *}$ & $0,289^{*}$ \\
Pemeliharaan & $0,612^{* *}$ & $0,385^{* *}$ & $0,350^{* *}$ \\
Panen & $0,416^{* *}$ & $0,434^{* *}$ & $0,295^{*}$ \\
\hline
\end{tabular}

** berhubungan nyata pada 0,01

* berhubungan nyata pada 0,05

tingkatsosialisasiorangtua, kohesivitastemansebaya, kesulitan pelepasan lahan, dan luas penguasaan lahan keluarga, diuji dengan menggunakan uji regresi. Hasil uji regresi menunjukkan bahwa faktor yang berpengaruh ada dua, yaitu tingkat sosialisasi orangtua dan tingkat kohesivitas teman sebaya (Tabel 2).

Pengaruh masing-masing variabel bisa dilihat dari hasil perbandingan antara nilai $\mathrm{t}$ hitung dan $\mathrm{t}$ tabel. $T$ tabel diperoleh sebesar 2,77 dengan tingkat probabalitas sebesar 0,05 dan derajat bebasnya 4 . Pengujian secara regresi akan menunjukkan nila $\mathrm{t}$ hitung. Jika $\mathrm{t}$ hitung lebih besar daripada $\mathrm{t}$ tabel, maka variabel tersebut berpengaruh, begitu juga sebaliknya. Ketika variabel nilai t hitung lebih kecil daripada nilai t tabel, maka variabel yang sedang diuji dapat dikatakan tidak ber-pengaruh. Besarnya pengaruh suatu variabel, dapat dilihat dari nilai signifikansi. Nilai signifikansi akan semakin bagus ketika mendekati nilai 0 (nol).

\section{Faktor-faktor yang Menentukan Keterlibatan Pemuda pada Kegiatan Persiapan Lahan dan Benih}

Pengujian dengan model regresi juga dapat membantu dalam memperoleh nilai $\mathrm{R}$ Square $\left(\mathrm{R}^{2}\right)$ yang menunjukkan besarnya pengaruh dari keempat variabel berpengaruh terhadap variabel terpengaruh. Angka R Square yang diperoleh adalah 0,606. Ini berarti bahwa kontribusi pengaruh variabel sosialisasi orangtua, kohesitas antar teman sebaya, kesulitan pelepasan lahan, dan luas penguasaan lahan keluarga terhadap variabel tingkat keterlibatan pemuda pada kegiatan persiapan lahan dan benih adalah sebesar $60,3 \%$ dan sisanya $39,7 \%$ merupakan kontribusi pengaruh dari variabel lain seperti tingkat pendidikan pemuda, umur, dan faktor-faktor lainnya yang tidak menjadi kajian utama pada penelitian ini. Hal ini mengindikasikan bahwa pengaruh dari keempat faktor tersebut dominan terhadap keterlibatan para pemuda pada kegiatan pertanian. Semakin tinggi atau kuat bertahannya dari faktor tersebut, maka keterlibatan pemuda pada kegiatan persiapan lahan dan benih juga akan semakin kuat. Namun, ketika faktor tersebut terabaikan, maka keterlibatan pemuda pada kegiatan persiapan lahan dan benih juga akan rendah.

Faktor yang ikut menentukan keterlibatan pemuda pada kegiatan persiapan lahan adalah kohesivitas teman sebaya. Keengananan pemuda untuk terlibat pada kegiatan persiapan lahan dan benih disebakan pandangan negartif pemuda terhadap pekerjaan pada tahap ini. Pemuda berpandangan bahwa pekerjaan pada tahap ini merupakan pekerjaan yang kotor. Mereka malu dilihat oleh teman-temannya ketika pulang dari sawah dengan pakaian yang penuh lumpur sawah. Rasa malu dan takut dijauhi dari pergaulan inilah yang membuat pemuda enggan untuk terlibat pada tahapan ini.

Berbeda dengan teman sebaya, orang tua tidak berpengaruh terhadap keterlibatan pemuda pada kegiatan persiapan lahan dan benih. Pemuda seringkali menolak permintaan orangtua untuk membajak sawah dengan alasan kesibukan sekolah dan pekerjaan pada sektor lain. Alasan ini cukup kuat karena pekerjaan pada sektor persiapan lahan dan benih menyita banyak waktu dan tenaga. Pemuda harus menyediakan beberapa hari untuk menekuni kegiatan ini. Pekerajaan harus dimulai pagi hari dan diakhiri pada sore harinya.

Tingkat penguasaan lahan dan luas lahan juga tidak berpengaruh terhadap keterlibatan pemuda pada 
kegiatan persiapan lahan. Lahan tidak lagi menjadi simbol lapisan sosial sehingga masyarakat sangat mudah dalam memutuskan untuk menjual lahan pertaniannya. Proses jual beli lahan sangat mudah. Transaksi jual beli lahan dapat dilakukan hanya dalam waktu satu hari. Hal ini mengindikasikan bahwa telah terjadi memudarnya security land di Desa Purwabakti. Hal ini berimplikasi pada luas kepemilikan lahan yang semakin sedikit. Semakin sedikitnya luas penguasaan lahan keluarga, membuat pemuda tidak memiliki pilihan selain bekerja pada sektor lainnya di luar pertanian.

\section{Faktor-faktor yang Menentukan Keterlibatan Pemuda pada Kegiatan Pemeliharaan}

Nilai R Squere untuk pengaruh sosialisasi orangtua, kohesitas dengan teman sebaya, kesulitan pelepasan lahan, dan luas penguasaan lahan keluarga terhadap variabel tingkat keterlibatan pemuda pada kegiatan pemeliharaan adalah sebesar $62,4 \%$, sedangkan $37,6 \%$ sisanya merupakan pengaruh dari variabel lainnya diluar keempat variabel tersebut seperti tingkat pendidikan pemuda, umur, dan faktorfaktor lainnya yang tidak menjadi kajian utama pada penelitian ini. Sebagaimana telah disinggung pada identifikasi keterlibatan pemuda pada kegiatan persiapan lahan dan benih, keterlibatan pemudanya ternyata sangatlah rendah dibandingkan dengan keterlibatan pada kegiatan persiapan lahan dan benih dan panen. Maka bisa disinyalir bahwa telah terjadi pengabaian pemanfaatan keempat faktor tersebut dalam usaha meningkatkan keterlibatan pemuda pada kegiatan pemeliharaan. Bisa saja karena teman yang membawa pengaruh negatif terhadap pemuda, dalam konteks pertanian, sehingga mereka tidak mau lagi bertani, atau karena sistem nilai dan proses pelepasan lahan yang semakin mudah sehingga banyak pemuda yang tidak mau bertani.

Faktor-faktor yang mempengaruhi keterlibatan pemuda pada kegiatan pemeliharaan ada dua, yaitu tingkat sosialisasi orangtua dan kohesivitas teman sebaya. Sebagaimana telah disinggung sebelumnya, pemuda yang tidak mau bertani, biasanya beralasan sekolah dan bekerja pada sektor lain kepada orangtuanya. Namun, alasan ini tidak berlaku karena pekerjaan pada kegiatan pemeliharaan tergolong pekerjaan yang tidak membutuhkan banyak tenaga dan memakan waktu lama. Pekerjaan ini bisa dilakukan disela-sela waktu luang pemuda, baik pagi atau sore hari.

Keengganan pemudauntuk bertani pada tahap pemeliharaan juga dipengaruhi oleh kohesivitas teman sebaya. Hal ini ber-kaitan dengan kebiasaan pemuda Desa Purwabakti untuk bermigrasi setelah masa tanam selesai. Mereka biasanya pergi ke kota untuk menjadi buruh bangunan rombongan. Selain itu, ada juga diantara mereka yang menjadi pedagang kusen atau lemari keliling.

\section{Faktor-faktor yang Menentukan Keterlibatan Pemuda pada Kegiatan Panen}

Berbeda dengan keterlibatan pada kegiatan persiapan lahan dan benih serta kegiatn pemeliharaan, pengaruh sosialisasi orangtua, kohesitas dengan teman sebaya, kesulitan pelepasan lahan, dan luas penguasaan lahan keluarga terhadap variabel tingkat keterlibatan pemuda pada kegiatan panen memiliki nilai R Square yang rendah yaitu sebesar 25,3\%. Hal ini menunjukkan bahwa pengaruh dari keempat faktor tersebut terhadap keterlibatan pemuda pada kegiatan pertanian cukup kecil. Dengan kata lain, pemuda akan tetap melakukan kegiatan panen tanpa adanya pengaruh dari keempat faktor tersebut. Salah satu faktor diluar kajian penelitian yang membuat keterlibatan pemuda pada kegiatan panen tetap tinggi adalah kuatnya tradisi panen raya. Ketika musim panen tiba, masyarakat akan bersama-sama panen ke sawah. Semua anggota keluarga dilibatkan pada kegiatan ini, mulai dari anak-anak sampai orang dewasa. Kebiasaaan tersebut selalu dibangun sehingga ketika mereka dewasa pun tetap mau mengikuti panen.

Nilai R Square tersebut diperkuat dengan hasil pengujian regresi bahwa tidak ada satu pun faktor yang berpengaruh terhadap keterlibatan pemuda pada kegiatan panen. Tradisi panen raya masih sangat kuat dimasyarakat. Hal ini merupakan salah satu berwujudan dari rasa syukur dan suka cita atas hasil panen yang diperoleh. Oleh karena itu, keterlibatan pemuda pada kegiatan ini tetap tinggi walaupun sosialisasi orangtuanya tinggi ataupun rendah. Begitu juga dengan tingkat kohesivitas teman sebaya, tingkat kesulitan pelepasan lahan, dan luas penguasaan lahan keluarga. Tinggi rendahnya frekuensi dari variabel tersebut, tidak memiliki pengaruh terhadap keterlibatan pemuda 
pada kegiatan panen.

\section{Korelasi Bentuk Keterlibatan Pemuda pada Kegiatan Pertanian dengan Pertanian Berkelanjutan}

Terwujudnya sistem pertanian berkelanjutan memiliki tiga indikator utama yaitu kegiatan pertanian yang dilakukan dapat menjanjikan secara ekonomi, lahan yang digunakan dapat tetap terjaga kesuburannya, dan juga kegiatan pertanian tersebut bisa diterima oleh masyarakat sebagai salah satu mata pencaharian yang layak dan tidak memalukan (Tabel 3). Tabel 3 menunjukkan pandangan pemuda mengenai pertanian yang berkelanjutan di desanya, baik dari aspek ekonomi, ekologi, mau pun sosial. Pada aspek kelayakan ekonomi, sebanyak 13,33\% responden menyatakan bahwa profesi sebagai petani memiliki tingkat kelayakan ekonomi yang tinggi, sebanyak 43,33\% menyatakan bahwa pertanian memiliki tingkat kelayakan ekonomi sedang, dan 43,33\% juga memiliki pandangan bahwa pertanian memiliki tingkat kelayakan ekonomi yang rendah. Hal ini merupakan realitas yang ada di Purwabakti. pertanian dianggap sebagai pekerjaan yang tidak menjanjikan secara ekonomi. Kebanyakan pemuda yang bermatapencaharian sebagai petani memiliki penghasilan yang rendah sedangkan pekerjaannya menyita banyak waktu dan tenaga. Sebelum bertani, mereka masih sering berkumpul sekedar untuk berbincang di warung kopi. Tetapi setelah bertani, mereka sudah mulai jarang berkumpul karena kelelahan setelah bertani, dan hasil yang diperoleh tidak seberapa. Teman-temannya yang bertani tetap kesulitan dalam masalah keuangan, sehingga tidak mengherankan jika pemuda meninggalkan pertanian. tidak ada yang mau mengalami kesulitan keuangan seperti halnya yang dialami oleh temantemannya yang bertani.

Hal yang bertolak belakang disampaikan oleh salah seorang ketua RT dan sekaligus sebagai inisiasi pertanian di Desa Purwabakti, yang menyatakan bahwa pertanian masih menjanjikan secara ekonomi, dengan syarat kegiatan pertanian harus dilakoni dengan penuh kesungguhan. Namun, kebanyakan pemuda menjadikan pertanian hanyalah sebagai pekerjaan sampingan sehingga perhatiannya tidak terfokus pada peningkatan hasil pertanian. Tidak mengherankan jika hasil yang diperoleh tidak sesuai dengan yang diharapkan dan tidak mampu memenuhi kebutuhan.

Berbeda dengan tingkat kelayakan ekonomi, pemuda menilai bahwa lahan di desanya memiliki tingkat kelayakan ekologi yang tinggi. sebanyak $78,33 \%$ responden menyatakan bahwa profesi sebagai petani memiliki tingkat kelayakan ekologi yang tinggi, sebanyak 15\% menyatakan bahwa sektor pertanian memiliki tingkat kelayakan ekologi sedang, dan 6,67\% memiliki pandangan bahwa pertanian memiliki tingkat kelayakan ekologi yang rendah. Pada dasarnya, lahan pertanian di Desa Purwabakti merupakan lahan yang subur tetapi praktek pertanian selama ini yang menggunakan pestisida dan pupuk kimia, telah merusak struktur tanah. Akibatnya penghasilan pertanian semakin hari semakin menurun. Responden mengakui bahwa kegiatan pertanian yang dilakukan akan membuat lahan tetap subur dibandingkan dibiarkan terbengkalai begitu saja. Ada beberapa lahan di Desa Purwabakti yang dibiarkan ditumbuhi tanaman liar. Responden berpendapat bahwa pemanfaatan lahan untuk pertanian justru menjaga kelestarian lahan. Berbagai hewan seperti cacing, belalang, kumbang, masih bisa ditemukan dengan mudah di lahan pertanian penduduk. Hewan-hewan tersebut akan menjaga kesuburan lahan dan membantu proses penyerbukan padi. Tanaman yang bisa tumbuh di Desa Purwabakti juga tidak terbatas pada tanaman padi saja. Berbagai tanaman lain seperti cabe, sayursayuran, dapat tumbuh dengan subur dengan hasil yang tinggi. Hal ini semakin membuktikan bahwa kondisi ekologi lahan di Desa Purwabakti masih sangat terjaga.

Senada dengan kelayakan ekologi, pemuda berpendapat bahwa pertanian masih diterima sebagai mata pencaharian yang layak oleh masyarakat. Sebanyak $70 \%$ responden menyatakan bahwa profesi sebagai petani memiliki tingkat kelayakan sosial yang tinggi, sebanyak $21,67 \%$ menyatakan bahwa pertanian memiliki tingkat kelayakan sosial sedang, dan 8,33\% memiliki pandangan bahwa pertanian memiliki tingkat kelayakan sosial yang rendah. Sebagai salah satu desa yang sejak dahulu telah menggeluti dunia pertanian, kehidupan ala petani seperti kerja berkelompok, saling membantu, dan juga bergotong royong, dapat ditemukan dalam kehidupan sehari-hari masyarakat Desa Purwabakti. Sebagai petani, mereka harus memulai menanam 
pada masa yang sama, dan akan panen pada saat yang bersamaan pula. Hal ini dilakukan agar hama bisa terkendali. Jika masa tanam tidak dilakukan dengan serempak, maka populasi hama akan membesar karena persediaan makanannya selalu ada sepanjang tahun. Walaupun mata pencaharian masyarakat sudah mulai bergeser meninggalkan sektor pertanian, namun kehidupan sosial ala masyarakat pertanian masih bisa ditemukan dalam kehidupan masyarakat Desa Purwabakti. Oleh karena itu, masyarakat Desa Purwabakti masih menganggap pertanian sebagai pekerjaan yang layak dipertahankan sehingga pemuda yang bekerja sebagai petani pun tidak dianggap rendah oleh masyarakat.

\section{Hubungan Keterlibatan Pemuda pada Kegiatan Pertanian dengan Pertanian Berkelanjutan}

Telah dijelaskan pada bagian pembahasan sebelumnya, keterlibatan pemuda pada setiap tahapan kegiatan pertanian sangatlah berbeda tergantung dengan faktor-faktor yang ikut mempengaruhinya. Keterlibatan para pemuda pada kegiatan pertanian diharapkan akan dapat memberikan sumbangsih terhadap pertanian berkelanjutan di desa tersebut. Oleh karena perlu dikaji hubungan antara keterlibatan pemuda pada kegiatan pertanian dengan pertanian berkelanjutan. Hubungan tersebut bisa diperoleh dengan melakukan uji korelasi rank Spearman (Tabel 4).

Semua faktor yang telah diuji berhubungan dengan pertanian berkelanjutan di Desa Purwabakti. Kuat lemahnya hubungan dilihat dari nilai koefisien korelasi bahwa keterlibatan pemuda pada tahapan kegiatan persiapan lahan memiliki hubungan yang kuat dengan kelayakan ekonomi, namun berhubungan lemah dengan kelayakan ekologi dan sosial. Begitu juga dengan keterlibatan pemuda pada tahapan kegiatan pemeliharaan lahan yang berhubungan kuat dengan kelayakan ekonomi dan berhubungan lemah dengan kelayakan ekologi dan sosial. Namun, hubungan antara keterlibatan pemuda pada kegiatan panen, berhubungan lemah dengan pertanian berkelanjutan di Purwabakti.

Sebagaimana telah disinggung sebelumnya, kegiatan persipan lahan membutuhkan banyak waktu dan tenaga dibandingkan dengan kegiatan pada tahapan lainnya. Pemuda harus membajak sawah, meratakan, serta mempersiapkan benih sebelum masa tanam dimulai. Kegiatan ini dinilai sebagai pekerjaan yang kotor dan kuno bagi pemuda. Banyak teman-temannya yang tidak mau terlibat pada kegiatan pertanian. Oleh karena itu, banyak pertimbangan sekali pertimbangan yang membuat pemuda mau terlibat atau pun meninggalkannya, terutama masalah sektor ekonomi. Sebanyak 43,33\% pemuda berpandangan bahwa sektor pertanian tidak layak secara ekonomi. Pendapatan yang diperoleh dari kegiatan pertanian, tidak mampu memenuhi kebutuhan primer dan sekunder. Penghasilan yang diperoleh ketika bertani pada tahap persiapan lahan dan benih cenderung rendah jika dibandingkan dengan penghasilan pada kegiatan pertanian pada tahap lainnya. Waktu yang dibutuhkan untuk mempersiapkan lahan dengan ukuran 1 gedeng (gedeng merupakan satuan pennghituan padi di Desa Purwabakti. Pengukuran 1 gedeng setara dengan 10 liter padi. Benih yang dibutuhkan untuk menanam $1.500 \mathrm{~m} 2$ adalah 1 gedeng) benih adalah 2 hari. Setiap harinya diberikan upah sebesar Rp 25.000. Hasil jerih payah selama dua hari hanya mendapatkan upah sebesar Rp 50.000. Hal inilah yang menyebabkan pemuda semakin enggan untuk terlibat pada kegiatan persiapan lahan dan benih.

Keterlibatan pemuda pada rangkaian kegiatan pemeliharaan berhubungan kuat dengan pertanian berkelanjutan pada aspek kelayakan ekonomi, sedangkan dengan aspek kelayakan ekologi dan sosial berhungan lemah. Kebiasaan pemuda Desa Purwabakti untuk pergi merantau setelah masa tanam selesai, mengakibatkan pemuda sangat enggan untuk terlibat pada tahapan ini. Mereka merantau untuk bekerja sebagai buruh bangunan rombongan. Oleh karena itu, mereka akan membandingkan penghasilan yang diperoleh pada kegiatan pertanian dengan penghasilan yang diperoleh pada saat mereka merantau dan bekerja pada sektor lain. Penghasilan yang dinilai lebih sedikit dan belum mampu memenuhi kebutuhan, membuat kebiasaan merantau ini tetap bertahan sampai saat ini.

Ada dua hal yang menarik yang terdapat pada hasil pengujian rank spearman. Pertama, keterlibatan pemuda pada kegiatan panen sama berhubungan lemah dengan pertanian berkelanjutan, baik kelayakan ekonomi, ekologi, ataupun sosial. Kuatnya tradisi panen raya membuat pemuda tetap mau mengikuti rangkaian kegiatan panen. mereka tidak begitu mempermasalahkan penghasilan yang 
diperoleh pada kegiatan ini. Kedua, keterlibatan pemuda pada kegiatan pertanian berhubungan lemah dengan kelayakan ekologi dan sosial. Lemahnya hubungan ini menunjukkan bahwa para pemuda desa mulai mengabaikan kesuburan lahan dan pandangan masyarakat mengenai pertanian. Pemuda berpandangan bahwa terlibat atau tidaknya dia pada rangkaian kegiatan pertanian, tidak akan berpengaruh terhadap kesuburan lahan di Desa Purwabakti. Hal ini tentu saja merupakan pandangan yang salah, kesuburan lahan akan rusak ketika dibiarkan tidak ditanami dan dirawat dengan baik. Begitu juga dengan pandangan para pemuda terhadap kegiatan pertanian. semakin enggannya pemuda untuk bertani, akan memungkinkan bergesernya pendapat masyarakat mengenai pertanian. saat ini masyarakat masih menganggap pertanian sebagai pekerjaan yang layak, akan sangat memungkinkan beberapa tahun yang akan datang, masyarakat menganggap pertanian sebagai pekerjaan yang kotor dan tidak layak karena pertanian menjadi sesuatu hal yang asing bagi pemudanya.

\section{Kesimpulan}

Keterlibatan pemuda pada kegiatan pertanian semakin menurun, terutama pada tahapan persiapan lahan, benih, dan pemeliharaan. Keterlibatan pemuda pada kegiatan panen sangat tinggi karena adanya tradisi panen raya, yang mengajak semua anggota keluarga untuk bersuka cita panen di sawah keluarga. Keengganan pemuda untuk terlibat pada kegiatan pertanian erat kaitannya dengan pengaruh sosialisasi orangtua dan kohesivitas teman sebaya; 4) pelaksanaan security land sudah mulai memudar sehingga transaksi jual beli lahan bisa dilaksanakan dalam waktu yang singkat; 5) memudarnya security land membuat kepemilikan lahan semakin sedikit karena seringkali dijual ketika pemiliknya mengalami kesulitan ekonomi; 6) pemuda mengasumsikan bahwa penghasilan yang diperoleh pada kegiatan pertanian tidak mampu memenuhi kebutuhan primer dan sekundernya; 7) pemuda berpandangan bahwa kelayakan ekologi atau kesuburan lahan di lahan pertanian sawah di desa purwabakti, masih tergolong subur saat ini dan beberapa tahun yang datang; 8) pemuda berpandangan bahwa masyarakat desa masih menerima pertanian sebagai pekerjaan yang layak. Tidak ada perbedaan pemuda yang bekerja pada sektor pertanian atau pun di luar pertanian. Pemuda enggan bertani karena penghasilan yang diperoleh jauh lebih sedikit dibandingkan pekerjaan pada sektor lain di luar pertanian.

Atas dasar kesimpulan di atas, maka saran penelitian diperuntukkan bagi orangtua, pemuda, pemerintah, dan akademisi sebagai berikut: pertama, orangtua berpengaruh terhadap keterlibatan pemuda pada kegiatan pemeliharaan. Oleh karena itu, perlu adanya perhatian yang besar dari orangtua dalam mensosialisasikan pertanian kepada pemuda dengan cara mengajak anak-anaknya untuk bertani. Pembelajaran dengan cara mengajak anak-anak untuk terlibat langsung pada kegiatan pertanian, akan membuat pengetahuan pemuda mengenai cara bercocok tanam menjadi lebih banyak dan aplikatif. Mengingat besarnya pengaruh teman sebaya terhadap keterlibatan pemuda pada kegiatan pemeliharaan, maka orangtua juga diharapkan bisa membatasi pergaulan pemuda sehingga pemuda tidak terkontaminasi hal-hal yang buruk dari lingkungan dan teman-temannya. Modal sosial yaitu orangtua dan teman sebaya bisa dimanfaatkan untuk meningkatkan keterlibatan pemuda pada kegiatan pertanian. Namun, cara yang dilakukan oleh orangtua dalam mempengaruhi anak-anaknya harus dirubah. Proses mempengaruhi teidak hanya didasarkan kepada nilai-nilai materialisme, tetapi justru memasukkan nilai-nilai sejarah pertanian dan kecintaan pada profesi sebagai petani. Kedua, White (2011) menjelaskan bahwa pertanian merupakan salah satu jenis pekerjaan yang mampu menyerap tenaga kerja dalam jumlah yang besar. Namun, hasil penelitian yang menunjukkan bahwa keterlibatan pemuda pada kegiatan pertanian yang semakin menurun. Akibatnya, indeks pengangguran usia produktif semakin meningkat. Oleh karena itu, pemuda diha-rapkan terlibat pada kegiatan pertanian dan bagi pemuda yang telah terlibat pada kegiatan pertanian, diharapkan untuk menularkan semangatnya kepada pemuda lainnya untuk bertani. Ketiga, pemerintah diharapkan dapat membentuk sebuah media untuk pendekatan pertanian yang ditujukan bagi pemuda. Seba-gaimana dijelaskan pada Undang-Undang No. 19 Tahun 2013 tentang Perlindungan dan Pemberdayaan Petani, pemerintah harus menyediakan fasilitas pendidikan formal dan informal yang berkelanjutan untuk peningkatan kemampuan petani. Tindakan ini diharapkan 
akan memunculkan kesadaran pemuda akan pentingnya pertanian. Selain itu, pemerintah harus bisa mengorganisir orangtua untuk meningkatkan sosialisasi mengenai pertanian kepada anakanak mereka, yang didukung dengan pemberian insentif modal serta jaminan pemasaran dengan cara menetapkan harga minimum hasil pertanian. Keempat, bagi akademisi, penelitian ini telah menganalisis mengenai faktor yang mempengaruhi keterlibatan pemuda pada kegiatan pertanian, yaitu sosialisasi orangtua, kohesivitas teman sebaya, kesulitan pelepasan lahan, dan luas penguasaan lahan keluarga. Pengaruh faktor-faktor tersebut sangat dominan, namun tentunya ada faktor lain yang mempengaruhi keterlibatan pemuda pada setiap tahap kegiatan pertanian. Oleh karena itu, diharapkan adanya penelitian lanjutan mengenai faktor-faktor lainnya yang mempengaruhi keterlibatan pemuda pada kegiatan pertanian, seperti adat istiadat, sejarah kejayaan pertanian masa lalu, serta kajian-kajian lainnya terkait dengan pemuda dan pertanian di Indonesia.

\section{Daftar Pustaka}

Ashari S. 2007. Pembangunan pertanian berkelanjutan melalui kemitraan usaha. Litbang Pertanian. 26(4): 123-130. [Internet]. [dapat diunduh dari: http://pustaka.litbang.go.id].

[BPS] Badan Pusat Statistik. 2010. Statistik pemuda indonesia. Jakarta (ID): BPS dan Ditjen PLS Depdiknas.

Hariadi SS. 2008. Urgensi pembangunan pedesaan dalam mewujudkan ketahanan pangan nasional. Ilmu-ilmu Pertanian. 4(2): 137-142. [Internet]. [dapat diunduh dari: http://stppyogyakarta. com].

Herlina. 2002. Orientasi nilai kerja pemuda pada keluarga petani perkebunan (studi kasus pada masyarakat perkebunan teh rakyat di Sukajembar, Kecamatan Sukanegara, Kabupaten Cianjur, Jawa Barat). [tesis]. Bogor (ID): Institut Pertanian Bogor.

Hidayat T. 2010. Kontestasi sains dan pengetahuan lokal petani dalam pengelolaan lahan rawa pasang surut Kalimantan Selatan. [tesis]. Wageningen [NL]: Wageningen Academic Publishers.

Untari et al. 2007. Implementasi Prinsip-Prinsip
Pertanian berkelanjutan oleh Petani di kabupaten kulon Progo. Ilmu-ilmu Pertanian. 3(2): 144155. [Internet]. [dapat diunduh dari: http:// stppyogyakarta.com].

Notohaprawiro T. 2006. Pembangunan pertanian berkelanjutan dalam konntek globalisasi dan demokratisasi ekonomi. Ilmu Tanah dan Lingkungan. 6(2): 137-142. [Internet]. [diunduh 27 Maret 2013].

Nugraha YA. 2012. Hubungan orangtua, media massa, dan teman dengan sikap pemuda terhadap pekerjaan di bidang pertanian (kasus pemuda di Cipendawa dan Sukatani, Kecamatan Pacet Kabupaten Cianjur). [tesis]. Bogor (ID): Institut Pertanian Bogor.

Priyatno D. 2013. Mandiri belajar analisis dengan SPSS. Yogyakarta (ID): MediaKom.

[UU] Undang-Undang Republik Indonesia Nomor 19 Tahun 2013 Tentang Perlindungan dan Pemberdayaan Petani. Republik Indonesia

[UU] Undang-Undang Republik Indonesia Nomor 40 Tahun 2009 Tentang Kepemudaan. Republik Indonesia

Singarimbun M, Effendi S. (editor). 2008. Metode Penelitian Survai. Jakarta (ID): LP3ES

Vellema S. 2011. Transformation and sustainability in agriculture: Connecting practice with social theory. Wageningen [NL]: Wageningen Academic Publishers.

White B. 2011. Who will own the countryside? dispossession, rural youth and the future of farming. International Institute of Social Studies. [Internet]. [dapat diunduh dari: http:// pustaka.litbang.go.id

Yennetri E. 1998. Faktor-faktor yang mempengaruhi kesempatan kerja dan transformasi tenaga kerja dari sektor pertanian ke sektor non pertanian di Sumatera Barat. [tesis]. Bogor (ID): Institut Pertanian Bogor. 182 hal. 